\title{
STUDI RETROSPEKTIF TERAPI ANTIDIABETIK PADA PENDERITA DIABETES MELITUS RAWAT INAP DI RUMAH SAKIT UMUM ARI CANTI PERIODE 2018
}

\author{
(A RETROSPECTIVE STUDY OF ANTIDIABETIC THERAPY ON HOSPITALIZED DIABETES \\ MELITUS PATIENTS IN GENERAL HOSPITAL OF ARI CANTI IN PERIOD OF 2018)
}

\author{
FITRIA MEGAWATI $^{\bullet}$, NI PUTU DEWI AGUSTINI ${ }^{2}$, NI LUH PUTU DIAN KRISMAYANTI ${ }^{3}$ \\ ${ }^{1}$ Fakultas Farmasi Universitas Mahasaraswati Denpasar, Jl. Kamboja No. 11A Denpasar, Bali
}

\begin{abstract}
Abstrak: Diabetes Melitus (DM) merupakan penyakit yang terjadi akibat adanya peningkatan kadar glukosa dalam darah. Diabetes melitus adalah penyakit yang tidak dapat disembuhkan tetapi hanya dapat mengontrol kadar gula darah di dalam tubuh dengan pemberian obat-obatan maupun insulin. Pengobatan Diabetes sering mengharuskan penggunaan terapi beberapa antidiabetik (terapi tunggal maupun kombinasi), termasuk terapi kombinasi antidiabetik oral yang berbeda golongan atau kombinasi Insulin untuk mencapai kadar glukosa darah normal. Penelitian ini bertujuan untuk mengevaluasi efektivitas terapi antidiabetik pada penderita Diabetes Melitus yang menjalani rawat inap di rumah sakit umum ari canti dengan penurunan kadar glukosa darah sewaktu periode 2018. Penelitian ini menggunakan desain penelitian kuasi eksperimental dengan pengambilan data menggunakan metode retrospektif. Penelitian ini menggunakan instrument berupa data rekam medis pasien dengan melihat data kadar glukosa sewaktu sebelum dan sesudah pasien DM menjalani rawat inap. Analisis data dilakukan dengan Uji T-tes dan mencari persentase jumlah pasien yan kadar glukosa $\leq 200 \mathrm{mg} / \mathrm{dL}$ sesudah rawat inap. Berdasarkan data hasil didapatkan bahwa pasien yang memiliki kadar glukosa darah sewaktu $\leq 200 \mathrm{mg} / \mathrm{dL}$ sesudah rawat inap sebanyak 62 orang (63\%) pasien. Dari hasil uji Paired T-test menunjukkan adanya perubahan yang signifikan $(\mathrm{p}<0,05)$ pada kadar glukosa darah sewaktu sebelum dan sesudah rawat inap pada pasien Diabetes Melitus di Rumah Sakit Umum Ari Canti baik dengan terapi antidiabetik tunggal ( $\mathrm{p}<0.001)$, kombinasi 2 macam obat ( $\mathrm{p}<0.001$ ), maupun dengan kombinasi 3 macam obat antidiabetik $(\mathrm{p}<0.008)$.
\end{abstract}

Kata Kunci: Andiabetik, Diabetes Melitus, Kadar Glukosa Darah Sewaktu.

\begin{abstract}
Diabetes mellitus (DM) is a disease that occurs due to an increase in glucose levels in the blood. Diabetes mellitus is an incurable disease, instead, blood sugar levels in it only could be controlled by administering drugs or insulin to the body. Treatment for diabetes often requires the use of several antidiabetic therapies (single or combination therapy), including the treatment of different combinations of oral antidiabetic groups or insulin combinations to achieve normal blood glucose levels. This study aims to evaluate the effectiveness of antidiabetic therapy in patients with diabetes mellitus who are hospitalized in public hospitals of Ari Canti within a decrease in blood glucose levels during the 2018 period. This study belongs to quasi experimental design in which the data retrieval employs the retrospective method. This research instruments are in the form of patient medical record data by observing at glucose level data both before and after DM patients undergo hospitalization. Data analysis was performed under T-test and discovering for the percentage of patients with glucose levels $\leq 200 \mathrm{mg}$ / dL after hospitalization. Based on the results of the data it was found that 62 people (63\%) patients had blood glucose levels at $\leq 200 \mathrm{mg} / \mathrm{dL}$ after hospitalization. From the results of the Paired T-test, it was shown a significant change $(\mathrm{p}<0.05)$ on blood glucose levels during and after hospitalization in patients with Diabetes Mellitus in Ari Canti General Hospital both with single antidiabetic therapy ( $\mathrm{p}<0.001$ ), combination of 2 types of drugs ( $\mathrm{p}<0.001$ ), or with a combination of 3 types of antidiabetic drugs ( $\mathrm{p}<0.008$ ).
\end{abstract}

Keywords: Andiabetik, Diabetes Melitus, Blood Glucose Level

\section{PENDAHULUAN}

Menurut Perkumpulan Endokrinilogi Indonesia (PERKENI, 2011) sampai saat ini penanganan Diabetes Melitus hanya dilakukan untuk mempertahankan kadar glukosa darah dalam batas normal. Pendekatan terapi yang diberikan tergantung pada tipe Diabetes. Pada Diabetes Melitus tipe I penanganan dilakukan dengan Insulin, sedangkan pendekatan farmakologis utama untuk mengatasi Diabetes Melitus tipe II adalah penggunaan obat Oral Antidiabetik (ADO). Pengobatan Diabetes Melitus sering mengharuskan penggunaan terapi beberapa antidiabetik (terapi

\section{• Correspondence email: f.mega83@gmail.com}


tunggal maupun kombinasi), termasuk terapi kombinasi antidiabetik oral yang berbeda golongan atau kombinasi Insulin untuk mencapai kadar glukosa darah normal (Wahyu, 2013). Pengobatan terapi yang diberikan dikatakan efektif jika kadar glukosa darah mencapai kadar glukosa darah normal.

Diabetes Melitus didefinisikan sebagai suatu penyakit atau gangguan metabolisme kronis dengan multi etiologi yang ditandai dengan tingginya kadar gula darah disertai dengan gangguan metabolisme karbohidrat, lemak, dan protein sebagai akibat insufisiensi fungsi insulin (WHO, 1999). Pada tahun 2015, Indonesia menepati urutan ketujuh di dunia untuk prevalensi penderita DM tertinggi di dunia bersama dengan Cina, India, Amerika Serikat, Brazil, Rusia dan Meksiko dengan estimasi jumlah penderita Diabetes Melitus sebanyak sepuluh juta (IDF Atlas, 2015). Diabetes Melitus disebut dengan the silent killer karena penyakit ini dapat mengenai semua organ tubuh dan menimbulkan berbagai keluhan. World Health Organization memprediksi adanya peningkatan jumlah penyandang diabetes yang cukup besar pada tahun-tahun mendatang. Melihat kenaikan prevalensi Diabetes Melitus secara global maka perlu dilakukan suatu penelitian tentang efektivitas terapi penggunaan antidiabetika tunggal dan kombinasi dalam mengendalikan gula darah. Dengan pelaksanaan yang baik, angka morbiditas dan mortalitas dapat diturunkan. Untuk menurunkannya, maka dilakukan pencegahan seperti modifikasi gaya hidup dan pengobatan secara farmakologi obat antidiabetik oral dan suntikan (Udayani, 2016).

Rumah sakit sebagai salah satu fasilitas pelayanan kesehatan memiliki peran yang sangat penting dalam upaya mempercepat peningkatan derajat kesehatan masyarakat. Pada era Jaminan Kesehatan Nasioanal (JKN), pemerintah telah menunjuk rumah sakit sebagai sarana pelayanan dan perawatan penyakit DM. Rumah Sakit Umum Ari Canti merupakan salah satu rumah sakit swasta di Kabupaten Gianyar yang melayani pengobatan rawat inap untuk penderita Diabetes Melitus. Penyakit Diabetes Melitus termasuk dalam 10 penyakit terbesar yang ada di Rumah Sakit Ari Canti.

Adapun tujuan dari penelitian ini yaitu untuk mengevaluasi besarnya efektivitas terapi antidiabetik baik tunggal maupun kombinasi pada penderita Diabetes Melitus yang melakukan rawat inap di Rumah Sakit Umum Ari Canti dengan penurunan kadar glukosa darah sewaktu dan mengetahui ada tidaknya perubahan kadar glukosa darah sewaktu sebelum dan sesudah rawat inap pada pasien Diabetes Melitus di Rumah Sakit Umum Ari Canti setelah mendapatkan terapi antidiabetik. Adapun rumusan masalah dalam penelitian ini adalah sebagai berikut:

1. Seberapa besar persentase efektivitas terapi antidiabetik baik tunggal maupun kombinasi pada penderita Diabetes Melitus di Rumah Sakit Umum Ari Canti dilihat dari penurunan kadar glukosa darah sewaktu sesudah rawat inap?

2. Adakah perubahan kadar glukosa darah sewaktu sebelum dan sesudah rawat inap pada pasien Diabetes Melitus di Rumah Sakit Umum Ari Canti setelah mendapatkan terapi antidiabetik?

\section{METODE PENELITIAN}

Penelitian ini dilakukan di Bagian Rekam Medik dan bagian keuangan di RS Ari Canti. Waktu penelitian dilakukan pada bulan Januari sampai dengan bulan Desember 2018 dengan mengambil data pada Rekam Medik pasien.

Penelitian ini merupakan penelitian quasi experimental design dimana jenis desain penelitian ini terdapat variabel-variabel dari luar yang tidak dapat dikontrol oleh peneliti. Pengambilan data menggunakan metode retrospektif didasarkan pada data rekam medik, dimana pada data rekam medis dilihat GDS awal pada saat pasien masuk rawat inap dan kemudian dilihat GDS saat pasien keluar rumah sakit.

Pada penelitian ini populasinya adalah seluruh penderita Diabetes Melitus dengan kode E.14.9 yang menjalani rawat inap di Rumah Sakit Umum Ari Canti Gianyar pada periode Januari Desember 2018. Populasi yang didapat yaitu sebanyak 171 orang. Sampel dari penelitian sebanyak 97 sampel. Sampel ini telah memenuhi beberapa kriteria diantaranya kriteria inklusi dan kriteria ekslusi sebagai berikut:

1. Kriteria Inklusi

a. Pasien Diabetes Melitus dengan kode E.14.9 yang melakukan rawat inap di Rumah Sakit Umum Ari Canti periode 2018.

b. Pasien Diabetes Melitus yang mendapatkan pengecekan laboratorium glukosa darah sewaktu sebelum dan sesudah melakukan perawatan rawat inap, serta memiliki data yang lengkap.

c. Pasien Diabetes Melitus yang mendapatkan obat antidiabetik oral maupun insulin baik tunggal maupun kombinasi. 
2. Kriteria Eksklusi

a. Pasien rawat inap Diabetes Melitus yang dirujuk dan meninggal.

b. Pasien dengan data yang tidak lengkap.

c. Pasien Diabetes Melitus yang tidak mengalami penurunan kadar glukosa darah sewaktu selama mendapatkan terapi antidiabetik.

d. Pasien yang kadar glukosa darah sewaktu awal tidak terdeteksi (kadar glukosa darah sewaktu terlalu tinggi/HI) pada saat pengecekan kadar glukosa darah.

Alur kerja pengumpulan data dalam penelitian ini, antara lain:

1. Melakukan studi pendahuluan dengan mencari data 10 Penyakit terbanyak Tahun 2018 dibagian Rekam Medik RSU Ari Canti.

2. Penyusunan proposal penelitian.

3. Pembuatan surat rekomendasi ijin penelitian dari kampus.

4. Pengajuan ijin penelitian di Rumah Sakit Umum Ari Canti.

5. Memilah data pasien Diabetes Melitus yang melakukan rawat inap periode 2018 .

Instrumen penelitian pada penelitian ini berupa dokumen resmi yaitu data rekam medik pasien. Data dianalisis dengan statistik deskriptif dan dibantu dengan menggunakan program SPSS (Statistical Product and Service Solution). Dalam analisis data dilakukan dengan dua cara, yaitu analisis univariat (deskriptif) dan bivariat (Uji Paired T-test).

\section{HASIL DAN PEMBAHASAN}

Dari data yang diperoleh melalui data rekam medik pasien rawat inap Diabetes Melitus di RSU Ari Canti tahun 2018, didapatkan populasi sebanyak 171 serta sampel sebanyak 97 orang yang telah memenuhi kriteria inklusi maupun eksklusi.
Tabel 1. Karakteristik Pasien Berdasarkan Umur

\begin{tabular}{ccc}
\hline Umur & Jumlah & \% \\
\hline 20-27 tahun & 1 & $1 \%$ \\
28-35 tahun & 3 & $3 \%$ \\
36-43 tahun & 13 & $14 \%$ \\
44-51 tahun & 12 & $12 \%$ \\
52-59 tahun & 31 & $32 \%$ \\
60-67 tahun & 21 & $22 \%$ \\
68-75 tahun & 10 & $10 \%$ \\
76-83 tahun & 6 & $6 \%$ \\
\hline Total & 97 & $100 \%$ \\
\hline
\end{tabular}

Pasien yang paling banyak menderita DM berumur antara 52-59 tahun. Hal ini dikarenakan semakin bertambahnya umur maka fungsi sel beta pankreas akan menurun dan semakin sedikit memproduksi insulin (Sepmawati, 2016). Selain itu, semakin bertambahnya umur akan mengurangi aktivitas fisik yang dilakukan sehingga menyebabkan terjadinya abnormalitas metabolisme glukosa di dalam tubuh dan penurunan jumlah reseptor insulin (Meneilly, 2010).

Tabel 2. Data Pasien Berdasarkan Jenis Kelamin

\begin{tabular}{ccc}
\hline Jenis Kelamin & jumlah & Persentase \\
\hline Laki-Laki & 57 & $59 \%$ \\
Perempuan & 40 & $41 \%$ \\
\hline Total & 97 & $100 \%$ \\
\hline
\end{tabular}

Pasien yang paling banyak menderita DM adalah laki-laki. Hal ini dikarenakan laki-laki memiliki tingkat stress yang lebih tinggi dibandingkan dengan perempuan. Manifestasi stress sering diakibatkan oleh kenaikan hormon stress seperti adrenalin dan kortisol yang melepaskan glukosa yang disimpan dalam darah, akibatnya adalah kenaikan kadar glukoda dalam darah (B. Michael, 2012). Selain itu, laki-laki juga memiliki resiko obesitas tinggi yang dapat menyebabkan hiperinsulinemia dan resistensi insulin (Kartika dkk, 2013).

Tabel 3. Data Penggunaan Terapi Antidiabetik Tunggal maupun Kombinasi di RSU Ari Canti

\begin{tabular}{cccc}
\hline \multicolumn{2}{c}{ TERAPI ANTIDIABETIK } & FREKUENSI & \% \\
\hline \multirow{2}{*}{ TUNGGAL } & & 36 & $37 \%$ \\
\multirow{2}{*}{ KOMBINASI } & 2 Macam Obat & 54 & $56 \%$ \\
& 3 Macam Obat & 7 & $7 \%$ \\
\hline \multicolumn{2}{c}{ TOTAL } & 97 & $100 \%$ \\
\hline
\end{tabular}


Penggunaan terapi terbanyak adalah kombinasi 2 macam obat antidiabetik yaitu 56\%. Sebagian besar kombinasi obat terdiri dari insulin rapid-acting (insulin kerja pendek) atau insulin prandial dengan insulin long-acting (insulin kerja panjang) atau insulin basal. Beberapa penelitian menunjukkan kombinasi 2 jenis insulin ini dapat memberikan penurunan kadar glukosa darah lebih baik karena dapat memenuhi kebutuhan insulin basal dan insulin prandial, mengontrol fluktuasi glukosa darah, kejadian hipoglikemia, dan peningkatan berat badan lebih terkontrol. Seperti yang diketahui, pada pasien DM terjadi gangguan pengeluaran insulin basal (puasa) dan prandial (setelah makan) untuk mempertahankan kadar gula darah dalam batas normal baik pada keadaan puasa maupun setelah makan. Untuk mencapai sasaran pengobatan yang baik, maka diperlukan insulin dengan karakteristik insulin menyerupai orang sehat yaitu kadar insulin yang sesuai dengan kebutuhan puasa dan setelah makan. Pemberian insulin basal dan prandial merupakan salah satu srategi pengobatan untuk memperbaiki kadar glukosa darah puasa atau sebelum makan. Oleh karena glukosa darah setelah makan merupakan keadaan yang dipengaruhi oleh kadar glukosa darah puasa, maka diharapkan dengan menurunkan kadar glukosa basal, kadar glukosa darah setelah makan juga menurun (Reni, 2011).

Tabel 4. Persentase efektivitas terapi antidiabetik tunggal dan kobinasi dilihat dari jumlah pasien dengan GDS normal $(\leq 200 \mathrm{mg} / \mathrm{dL})$ sesudah menjalani rawat inap di RSU Ari Canti

\begin{tabular}{|c|c|c|c|c|}
\hline \multirow{2}{*}{\multicolumn{2}{|c|}{ Penggunaan Antidiabetik }} & \multicolumn{2}{|c|}{$\begin{array}{c}\text { Kadar Glukosa Darah Sewaktu } \\
\text { Sesudah Rawat Inap }\end{array}$} & \multirow{2}{*}{$\begin{array}{l}\text { Persentase } \\
\quad(\mathrm{n}=97)\end{array}$} \\
\hline & & $\leq 200 \mathrm{mg} / \mathrm{dL}$ & $\geq 200 \mathrm{mg} / \mathrm{dL}$ & \\
\hline \multicolumn{2}{|c|}{ Tunggal } & 26 & 10 & $27 \%$ \\
\hline \multirow{2}{*}{ Kombinasi } & 2 macam obat & 33 & 21 & $34 \%$ \\
\hline & 3 macam obat & 3 & 4 & $3 \%$ \\
\hline
\end{tabular}

Banyaknya pasien yang memiliki kadar glukosa darah sewaktu $\leq 200 \mathrm{mg} / \mathrm{dL}$ sesudah rawat inap adalah 62 orang $(63 \%)$ pasien, dimana sebanyak 26 pasien atau $27 \%$ penderita DM yang mencapai target dengan terapi antidiabetik tunggal,
33 pasien atau $34 \%$ pasien yang mencapai target dengan terapi kombinasi 2 macam obat antidiabetik, dan sebanyak 3 pasien atau $6 \%$ yang yang mencapai target.

Tabel 5. Hasil Uji Efektivitas Antidiabetik menggunakan Uji T-Berpasangan dengan penurunan kadar glukosa darah sewaktu sebelum dan sesudah pasien Diabetes Melitus menjalani rawat inap

\begin{tabular}{|c|c|c|c|c|}
\hline & Rerata (s.b) & Selisih (s.b) & IK95\% & Nilai p \\
\hline GDS Awal (tunggal) $(\mathrm{n}=36)$ & $326.31(17.2)$ & $324.09(17.1)$ & $\begin{array}{l}3588.85- \\
2892.87\end{array}$ & $<0,001$ \\
\hline Trans_GDSAk1 $(n=36)$ & $2.30(0.03)$ & & & \\
\hline GDS Awal (2 obat) $(n=54)$ & $387.50(15.2)$ & $197.46(15.5)$ & $\begin{array}{c}2284.78- \\
1664.48\end{array}$ & $<0.001$ \\
\hline GDS Akhir ( 2 obat $)(n=54)$ & $190.04(10.7)$ & & & \\
\hline GDS Awal ( 3 obat) $(n=7)$ & $418.43(52.6)$ & $214.29(55.2)$ & $\begin{array}{c}3494.08- \\
791.64\end{array}$ & $<0.008$ \\
\hline GDS Akhir ( 3 obat) $(n=7)$ & $204.14(34.3)$ & & & \\
\hline
\end{tabular}

Keterangan s.b : simpangan baku

Efektivitas adalah keberhasilan antidiabetik untuk mencapai kadar gula darah target menuju target. Target gula darah adalah gula darah sewaktu (GDS) $\leq 200 \quad \mathrm{mg} / \mathrm{dL} \quad$ (American Diabetes Association (2013), Perkeni (2011)).

Dari hasil uji yang dilakukan dengan uji TBerpasangan (Paired T-test) pada pemberian terapi antidiabetik tunggal didapatkan rata-rata GDS Awal 326.31 dan GDS Akhir 2.30 dengan selisih sebanyak 324.09. Diperoleh nilai $p<0,001$ dengan taraf kepercayaan 95\%, rentang selisih kadar glukosa darah sewaktu sebelum dan sesudah menjalani rawat inap antara 358.885 sampai 289.287. Pada pemberian kombinasi 2 macam obat 
antidiabetik didapatkan rata-rata GDS awal 387.50 dan GDS akhir 190.04 dengan selisih sebanyak 197.46. Diperoleh nilai $\mathrm{p}<0.001$ dengan taraf kepercayaan $95 \%$, rentang selisih kadar glukosa darah sewaktu sebelum dan sesudah menjalani rawat inap 228.478 sampai 166.448. Pada pemberian kombinasi 3 macam obat antidiabetik didapatkan rata-rata GDS Awal 418.43 dan GDS Akhir 204.14 dengan selisih 214.29. Diperoleh nilai $\mathrm{p}<0.008$ dengan taraf kepercayaan 95\%, rentang selisih kadar glukosa darah sewaktu sebelum dan sesudah menjalani rawat inap yakni 349.408 sampai 79.164. Oleh karena nilai $\mathrm{p}<0,05$ maka secara statistik terdapat perubahan yang bermakna pada penurunan kadar glukosa sewaktu sebelum dan sesudah pasien menjalani rawat inap dengan terapi antidiabetik tunggal, kombinasi 2 golongan obat antidiabetik, dan kombinasi 3 golongan antidiabetik.

\section{SIMPULAN}

Dari hasil penelitan yang telah dilakukan, dapat disimpulkan bahwa penggunaan antidiabetik kombinasi 2 macam obat memiliki persentase efektivitas tertinggi yaitu $34 \%$ dilihat dari jumlah pasien yang kadar gula darah sewaktu sesudah rawat inap $\leq 200 \mathrm{mg} / \mathrm{dL}$. Dari hasil uji Paired T-test menunjukkan adanya perubahan yang signifikan $(\mathrm{p}<0,05)$ pada kadar glukosa darah sewaktu sebelum dan sesudah rawat inap pada pasien Diabetes Melitus di Rumah Sakit Umum Ari Canti baik dengan terapi antidiabetik tunggal ( $p<0.001)$, kombinasi 2 macam obat ( $\mathrm{p}<0.001$ ), maupun dengan kombinasi 3 macam obat antidiabetik ( $\mathrm{p}$ $<0.008)$.

\section{UCAPAN TERIMAKASIH}

Ucapan terimakasih kepada seluruh pihak yang sudah membantu penelitian ini sehingga bisa berjalan dengan baik khususnya Rumah Sakit Ari Canti

\section{DAFTAR PUSTAKA}

American Diabetes Association (ADA), 2013. Standards of Medical Care in Diabetes2013. Diakses pada 10 Febuari 2019 dari:
http://care.diabetesjournals.org/content/36/S upplement_1/S11.full.pdf+html

Febriana, R. 2011. Forum Penunjang Medis. Diabetes Mellitus Dan Terapi Insulin.Vol.2.No.

Interntional Diabetes Federation. 2015, IDF Diabetes Atlas, $7^{\text {th }}$ Edition, Diakses pada 6 Februari 2019 <www.diabetesatlas.org>.

Septinawati, N.D. 2015. Evaluasi Ketepatan Terapi Pada Pasien Diabetes Mellitus Tipe 2 Di Instalasi Rawat Inap RS "A" Periode Januari-Juni 2015. Diakses tanggal $17 \mathrm{Mei}$ 2019

PERKENI, (2011). Konsesus dan Pencegahan Diabetes Melitus Tipe 2 Di Indonesia. Jakarta.

Putra, I.M.A.S., Udayani, N.N.W, Meriyani, H. 2017. Medicamento. Analisis Efektivitas Biaya Penggunaan Terapi Insulin Dan Insulin Kombinasi Pada Pasien Diabetes Melitus Tipe II Rawat Jalan Di RSUP Sanglah. Vol.3 No.2. 103.

Profil, 2019, Profil Rumah Sakit Umum Ari Canti Gianyar $2019 \quad$ (online) .(http://rsaricanti.gianyar.go.id, diakses 28 Februari 2019).

Soegondo. 2002. Diabetes Melitus Penatalaksanaan Terpadu. Jakarta: FKUI.

Udayani, N.N.W., Meriyani, H. 2016. Perbedaan Efektivitas Penggunaan Antidiabetik Oral Tunggal Dengan Kombinasi Pada Pasien DM Tipe 2 Di UPT. Puskesmas Dawan II Kabupaten Klungkung Periode November 2015-Februari 2016. Diakses pada 18 Mei 2019 dari http://journal. farmasisaraswati.ac.id/index.php/mento/arti cle/download/antidiabetik\%20oral/pdf_21

World Health Organization.1999. Definition, Diagnosis dan Classification of Diabetes Mellitus and its Complication. Departement of Noncommucable Disease Surveilance Geneva. 